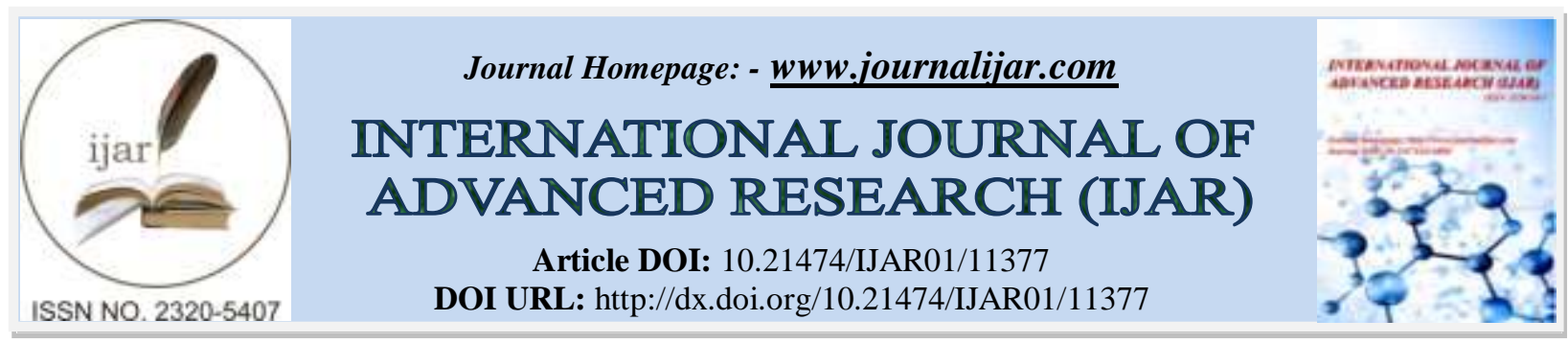

RESEARCH ARTICLE

\title{
AN OBSERVATIONAL STUDY OF SEVERE PRE-ECLAMPSIA IN PREGNANCY AT TERTIARY HEALTH CARE CENTER OF CENTRAL INDIA
}

\author{
Rekha Vimal Gupta ${ }^{1}$, Parul Trichal ${ }^{2}$ and Gangwar Pooja ${ }^{3}$
}

Obstetric and Gynacology, Government Medical College, Ratlam, Madhya Pradesh, India.

\section{Manuscript Info (.......................... \\ Manuscript History \\ Received: 20 May 2020 \\ Final Accepted: 24 June 2020 \\ Published: July 2020 \\ Key words:- \\ Severe Pre-Eclampsia, Pre- Eclampsia, Eclampsia, Cesarean Section}

\begin{abstract}
Introduction: To study the effect of age, parity, mode of delivery and perinatal outcome in pregnant women with severe pre-eclampsia.

Method: The study covers 2 year period, during which 480 patients with severe pre-eclampsia were selected, treated and delivered. The study was focussed on age, parity, mode of delivery and perinatal outcome including birth weight and frequency of stillbirths in severe pre-eclampsia patients.

Result: In this study a high proportion $(56.0 \%)$ was nulliparous women. Similarly, severe pre-eclampsia was encountered at a high percentage $(45.5 \%)$ in women at the $20-24$ years of their reproductive age, and maximum women with severe pre-eclampsia delivered at 37 weeks or more $(80 \%)$. Spontaneous vaginal deliveries were less frequent in women with severe pre-eclampsia (34.5\%) as compared to cesarean (60.5\%). Cesarean section was mostly done due to fetal distress $(44.9 \%)$. The perinatal outcome with severe pre-eclampsia shows $5.5 \%$ of fetal demise, out of which stillbirths (2.5\%) and IUD (3\%).

Conclusion: In our study we found a high proportion of severe preeclampsia cases occurring among nulliparous women and 20-24 years of age. There is also an increased incidence of cesarean section among the severe pre-eclampsia and were mostly due to fetal distress.
\end{abstract}

Copy Right, IJAR, 2020,. All rights reserved.

\section{Introduction:-}

Pre-eclampsia and eclampsia are important causes of maternal morbidity and mortality for mother and her child, although outcome is commonly good [1]. Preeclampsia and eclampsia probably account for about 50,000 maternal deaths a year [2]. Pre-eclampsia is a pregnancy specific syndrome that occurs after 20 weeks of gestation. It is a multisystem disorder of pregnancy usually related to raised blood pressure and proteinuria and complicates 2-8\% of pregnancy [3]. The standards for diagnosis are, raised pressure level of Systolic BP of $140 \mathrm{mmHg}$ or higher and Diastolic BP of $90 \mathrm{mmHg}$ or higher after 20 weeks of gestation in a women with previously normal blood pressure and proteinuria defined as urinary excretion of $0.3 \mathrm{~g}$ protein or higher during a 24 hours urine specimen. Preeclampsia is accounted severe [4] if systolic BP of $160 \mathrm{mmHg}$ or higher and Diastolic BP of $110 \mathrm{mmHg}$ or higher on two occasions minimum of 6 hours apart while the patient is at bed rest or with proteinuria of $5 \mathrm{~g}$ or higher during a 24 hours urine specimen or $3+$ or greater on two random urine samples collected a minimum of 4 hours apart or 
with sign, symptoms or laboratory values of severe preeclampsia with elevated BP with one or more of the following criteria:

Oliguria of less than $500 \mathrm{ml}$ urine in 24 hours. Cerebral or visual disturbance Pulmonary oedema Epigastric or right upper quadrant pain. Impaired liver function. Thrombocytopenia. Fetal growth restriction.

\section{Materials And Methods:-}

This study “An observational Study of Severe Pre-Eclampsia in Pregnancy” was done in Department of Obstetrics and Gynaecology, Goverrnment Medical College Ratlam, Madhya Pradesh, India and covered a period of 1 year from 1st July 2018 to 31st June 2020. During the study period, 480 pregnant women with severe pre-eclampsia were admitted and treated. Pre-eclampsia is said to be severe in patients beyond 20weeks of pregnancy or during labour having one or more of the following criteria- Systolic BP of $160 \mathrm{mmHg}$ or higher and daistolic BP of $110 \mathrm{mmHg}$ or higher on two occassions a minimum of 6 hours apart while the patient is at bed rest, proteinuria of $5 \mathrm{~g}$ or higher in 24 hour urine specimen or 3+ or greater on two random urine samples collected a minimum of 4 hours apart (even if $\mathrm{BP}$ is within the mild range), oliguria or less than $500 \mathrm{ml}$ urine in 24 hours, cerebral or visual disturbance, including altered consciousness, persistent headache, scotoma or blurred vision, pulmonary oedema, epigastric or right upper quadrant pain or elevated serum liver transaminases without a known cause, impaired liver function, thrombocytopenia, with platelet count $\leq 100,000 / \mu 1$, fetal growth restriction, microangiopathic hemolytic anaemia (raised bilirubin $>1.2 \mathrm{mg} \%$, LDH $>600 \mathrm{IU} / \mathrm{L}$, low haptoglobin). A detailed history was taken from the patients and complete examination was done at the time of admission. Investigations done were, Blood grouping, Routine examination of blood, Platelet count, RBS, Blood urea, Serum creatinine, Serum uric acid, LDH, Liver function test, Coagulation studies if platelet count $<1$ lakh, ECG, Urine albumin by dipstick done. Evaluation of fetal size, weight and well- being and liquor volume with ultrasound was done. The antihypertensive used were alpha methyl dopa and labetalol. Progress of labour was monitored by a partograph recording. Patients were either induced or allowed for spontaneous labour. Neonatal outcomes were assessed. The infornation collected from the subsequent observations were statistically analysed using Chi- square test and student $\mathrm{t}$ test.

\section{Observation Table:-}

Table 1:- Age distribution of patients.

\begin{tabular}{|l|l|l|}
\hline AGE IN YEARS & NUMBER OF CASES & PERCENTAGE (\%) \\
\hline $19-24$ & 35 & 7.3 \\
\hline $25-29$ & 225 & 46.8 \\
\hline$>29$ & 140 & 29.2 \\
\hline TOTAL & 80 & 16.7 \\
\hline
\end{tabular}

In this table most of the cases i.e. $46.8 \%$ belonged to the age group of 20-24 years. Mean age was 24.68 years $\pm(4.678 S D)$, Median-24years.

Table 2:- Distribution of patients based on parity.

\begin{tabular}{|l|l|l|}
\hline PARITY & NUMBER OF CASES & PERCENTAGE (\%) \\
\hline G1 & 278 & 58 \\
\hline G2 & 96 & 20 \\
\hline G3 & 58 & 12 \\
\hline G4 & 28 & 6 \\
\hline G5 & 9 & 1.9 \\
\hline G6 & 7 & 1.3 \\
\hline G7 & 4 & 0.8 \\
\hline
\end{tabular}

In our study, the highest incidence of severe pre-eclampsia was among the primigravidas (58\%) and is depicted in [TABLE-2].

Table 3:- Duration of pregnancy.

\begin{tabular}{|l|l|l|}
\hline $\begin{array}{l}\text { DURATION OF PREGNANCY } \\
\text { (IN WEEKS) }\end{array}$ & NUMBER OF CASES & PERCENTAGE (\%) \\
\hline $25-28$ & 5 & 1 \\
\hline $29-32$ & 14 & 3 \\
\hline $33-36$ & 77 & 16 \\
\hline$>37$ & 384 & 80 \\
\hline
\end{tabular}




\begin{tabular}{|l|l|l|}
\hline TOTAL & 480 & 100
\end{tabular}

In this table the gestational age $80 \%$ were term gestation being 37 weeks or more. Mean duration of gestation was 38.62 weeks $\pm(2.887 \mathrm{SD})$, Median was 40 weeks of gestation..

Table 4:- Mode of delivery.

\begin{tabular}{|l|l|l|}
\hline MODE OF DELIVERY & NUMBER OF CASES & PERCENTAGE (\%) \\
\hline $\begin{array}{l}\text { SPONTANIOUS VAGINAL } \\
\text { DELIVERY }\end{array}$ & 168 & 35 \\
\hline INDUCTION & 24 & 5 \\
\hline LSCS & 288 & 60 \\
\hline TOTAL & 480 & 100 \\
\hline
\end{tabular}

As shown in table spontaneous vaginal deliveries were less frequent in women with severe pre-eclampsia (35\%) as compared with caesarean section $(60 \%)$.

Table 5:- Indication of operative interference.

\begin{tabular}{|l|l|l|}
\hline $\begin{array}{l}\text { INDICATION OF OPERATIVE } \\
\text { INTERFERENCE }\end{array}$ & NUMBER OF CASES & PERCENTAGE (\%) \\
\hline Fetal Distress & 201 & 42 \\
\hline Oligohydramnios & 58 & 12 \\
\hline Post CS & 43 & 9 \\
\hline Induction Failure & 38 & 8 \\
\hline Postdated & 15 & 3 \\
\hline IUGR & 28 & 6 \\
\hline Breech & 15 & 3 \\
\hline Others & 82 & 17 \\
\hline TOTAL & 480 & 100 \\
\hline
\end{tabular}

In this table caesarean sections were mostly due to fetal distress (42\%). Induction deliveries, with spontaneous labour, amounted to $12 \%$ in women with severe pre-eclampsia.

Table 6:- Weight of baby at birth.

\begin{tabular}{|l|l|l|}
\hline WEIGHT OF BABY & NUMBER OF CASES & PERCENTAGE (\%) \\
\hline$\leq 1 \mathrm{KG}$ & 10 & 2 \\
\hline $1.1-2 \mathrm{KG}$ & 58 & 12 \\
\hline $2.1-3 \mathrm{KG}$ & 326 & 68 \\
\hline$>3 \mathrm{KG}$ & 86 & 18 \\
\hline TOTAL & 480 & 100 \\
\hline
\end{tabular}

In this table It was observed that, $68 \%$ of patients delivered babies with birth weight of $2.1-3 \mathrm{~kg}$. Mean birth weight was. $140 \mathrm{~kg} \pm(0.6264 \mathrm{SD})$, Median-2kg. The minimum birth weight was $700 \mathrm{gms}$ and the maximum birth weight was $4.2 \mathrm{~kg}$.

Table 7:- Fetal demise.

\begin{tabular}{|l|l|l|}
\hline FETAL DEMISE & NUMBER OF CASES & PERCENTAGE (\%) \\
\hline IUD & 15 & 3 \\
\hline STILL BORN & 13 & 2.7 \\
\hline TOTAL & 28 & 5.7 \\
\hline
\end{tabular}

In this table we found that, out of 480 patients, there were 452 live births and 28(5.7\%) fetal demise. Thus out of total perinatal mortality, $3 \%$ were IUD before admission and $2.7 \%$ were still birth.

\section{Results:-}

During the study period of 2 year, 480 pregnant women with severe pre-eclampsia were selected to determine the age, parity, gestational age, mode of delivery and perinatal outcome. As mentioned in [TABLE-1], in our study, most of the cases i.e. $46.8 \%$ belonged to the age group of 20-24 years. Mean age was 24.68 years $\pm(4.678 \mathrm{SD})$, Median-24years. minimum age was 18 years and maximum age seen was 38 years. In our study, the highest incidence of severe pre-eclampsia was among the primigravidas (58\%) and is depicted in [TABLE-2]. Regarding the 
gestational age, as shown in [TABLE-3], in our study $80 \%$ were term gestation being 37 weeks or more. Mean duration of gestation was 38.62 weeks $\pm(2.887$ SD), Median was 40 weeks of gestation. Minimum gestation at which severe preeclampsia occurred in our study was 27 weeks and the maximum was 43 weeks. As shown in [TABLE-4] and [TABLE-5], in our study, spontaneous vaginal deliveries were less frequent in women with severe pre-eclampsia (35\%) as compared with caesarean section (60\%). Caesarean sections were mostly due to fetal distress (42\%). Induction deliveries, with spontaneous labour, amounted to $12 \%$ in women with severe preeclampsia. It was observed that, $68 \%$ of patients delivered babies with birth weight of $2.1-3 \mathrm{~kg}$. Mean birth weight was. $140 \mathrm{~kg} \pm(0.6264 \mathrm{SD})$, Median- $2 \mathrm{~kg}$. The minimum birth weight was $700 \mathrm{gms}$ and the maximum birth weight was $4.2 \mathrm{~kg}$ as shown in [TABLE-6]. In our study we found that, out of 480 patients, there were 452 live births and $28(5.7 \%)$ fetal demise. Thus out of total perinatal mortality, $3 \%$ were IUD before admission and $2.7 \%$ were still birth, as depicted in [TABLE-7].

\section{Discussion:-}

In our study the occurrence rates of severe preeclampsia were highest in age group below 24 years. This is comparable to other studies which show the peak incidence of eclampsia in the teenage years and low twenties [4, 5]. The incidence of severe preeclampsia in nulliparous population was $58 \%$ in our studies. This is consistent with the high incidence and risk of severe pre-eclampsia in the nulliparous population. In our study $20 \%$ of the cases had severe preeclampsia preterm, out of which $16 \%$ were between 33-36 weeks. In the study by Seth et al, $47 \%$ patients were over 36 weeks gestation and $31.8 \%$ were between 32-36 weeks gestation[6] the disparity in gestational age in our study could be possibly due to late onset of severe pre-eclampsia in our study population. Regarding mode of delivery in our study we found that there was an increased in operative interference in patients with severe preeclampsia, which was mainly due to a high incidence of fetal distress. The higher rate of caesarean section was might be with an aim to prevent complications to the fetus as well as the mother.

\section{Conclusion:-}

In our study we found a high proportion of severe pre-eclampsia cases occurring among nulliparous women and those at the extreme ends of the reproductive age. There is also an increased incidence of caesarean section among the severe pre-eclampsia and were mostly due to fetal distress.

\section{Referrence:-}

1. The National Institute for Clinical Excellence, The Scottish Executive Health Department, The Department of Health, Social Services and Public Safety, Northern Ireland. Why mothers die 1997-1999: the confidential enquiries into maternal deaths in the United Kingdom. London: RCOG Press, 2001

2. Duley L; Maternal mortality associated with hypertensive disorders of pregnancy in Africa, Asia, Latin America and the Caribbean. Br J Obstet Gynaecol 1992; 99: 547-53.

3. Roberts JM; Magnesium for preeclampsia and eclampsia. N Engl J Med 1995; 333: 250-51.

4. Myatt L, Clifton RG, Roberts JM; First trimester prediction of preeclampsia in nulliparous women at low-risk. Obstet Gynecol 119(6); 2012a.

5. Myatt L, Clifton RG, Roberts JM; The utility of uterine artery Doppler velocimetry in prediction of preeclampsia in a low- risk population. Obstet Gynecol 120(4); 815, $2012 \mathrm{~b}$.

6. Shikha Seth, Nagrath A, Singh DK; Comparison of low dose, single loading dose, and standard Pritchard regimen of magnesium sulphate in antepartum eclampsia. Anatol J Obstet Gynecol 2010; 1:1. 